\title{
CORRELATION BETWEEN THE DEVELOPMENT OF INFORMATION TECHNOLOGY AND THE HABITUAL BEHAVIOR OF MILLENNIALS IN URBAN AREAS
}

\author{
Andini Nur Aulia \\ andininuraulia1008@gmail.com
}

\begin{abstract}
Information and Communication Technology is growing rapidly in the world's competition. This flow of development brings a big influence for its users including millennials who live in urban areas that always boast a western lifestyle culture that is reflected by the behavior of money-wasting habits that it has or called hedonism. This certainly causes the threat of degradation to the culture of local heritage that should be maintained by the nation's successors or millennials. But that the progress in the field of information technology brings positive good for the people but shifted the positive benefits due to the lack of a strong understanding of the nation's morality on the basis of Pancasila that should be owned by millennials. From the conclusion that can be drawn from this study that the advancement of information technology has an effect on the lifestyle and way of thinking of millennials so that it becomes a threat to the sustainability of local culture, therefore millennials as the next generation and savior of the nation should be equipped with an understanding of the nation's morality on the basis of Pancasila and its implementation in order to foster nationalism and realize the nation's strategy in overcoming degradation of local culture.
\end{abstract}

Keywords: Information Technology, Behavior, Millennials. 


\section{INTRODUCTION}

The rapid progress of technology is very visible in this day and age which is real for the state of the social environment. Science and Technology is a field that is used as a source of reference in order to interpret and understand the social environment of society and its content. Science and Technology were created to meet human needs that are very useful but also have an influence that will be received by its users that vary depending on the values, norms, morals and laws on which it is the main basis. Thus the creation of Science and Technology if without value will be dangerous and humans without science and technology reflect backwardness (Tumanggor; 2010).

Knowing the rapid development of information technology in the environment around us causes the compelled of a person or group to move with the current that brings them into the development of technological sophistication. This has become increasingly commonplace today, because if it does not follow the developments that occur it will be left behind and even excluded due to not updating information from technology. But it should also be noted that if you cannot use or manage technology reasonably or outside of actual needs, then the results are not maximal. In such a sophisticated technological development can slowly replace the position of human roles replaced by "robots".

With the increasing ease of information that comes through technology obtained by the community, especially millennials can affect lifestyle, perspective and culture in a particular area. The sophistication of information technology makes it easier for the social activities of its users such as interacting with each other even though it is limited to long distances. But on the other hand, information technology has a bad influence if it is not wise to use it as is often the case, namely fraud, data falsification, and other technology-based crime.

\section{METHODS}


The research method used in this article is a qualitative research method which is a research method that uses appropriate references in the field without manipulation and qualitatively collecting data (Arifin 2012: 10).

In this article using descriptive research approach as for descriptive method according to Arikunto (2010: 3) descriptive method is research that uses methods to investigate circumstances, conditions, situations, and other things.

Ratna (2012: 53) asserts that descriptive analytical research methods are a method of research that uses the technique of describing a series of facts that are then continued with analysis. So it can be concluded that descriptive research is a research method that observes a number of objects or phenomena for analysis in the next step.

In addition to using qualitative approach methods, this paper also uses approaches based on socio-cultural theory and behavioral psychology based on the type of research methods including methods of library study approach so that secondary data is obtained from relevant books, laws or regulations such as UUITE and the 1945
Constitution, data is also taken from internet infromation media and also from similar research analysis that has been published on other media pages.

\section{DISCUSSION}

The emergence of technology in the world of investment that is rife today and makes it an era of progress era makes technology is the only field that dominates the sophistication of the world of the era of progress of the era. So do not be surprised if in a group will be left behind the times if it does not follow the progress of information technology. In alisyahbana quote in his book Nanang Martono (2011), technology is a way that is done to meet human needs by using the help of tools and sense created, so that with the help of technological tools can develop, accelerate, make human sense tools more sturdy.

According to the Great Dictionary of Indonesian (Language Center 2011), Technology is defined as a tool that becomes a benchmark to achieve the goal of mastering applied science, or a means used to achieve needs and meet the comfort for human life. 
According to Henslin in nanang martono's proprietary book (2011), technology has a deeper meaning than other sophisticated equipment. Technology has a series framework for social culture around it, so that if technology undergoes changes or developments, then social culture such as human thinking and behavior around it will also experience the same changes or developments, for example that often occurs, namely the way humans interact with each other.

According to Soelaiman (2011), explaining that consists of four changes in the way people think or behave due to the development of technology, among others, the first is the emergence of Reification which means a symptom where there are things or changes that occur in the world of technology concerned economically, so that it can meet human needs, the second is manipulation where the human way of thinking has become manipulative because of technological capabilities that occur. Can make natural objects artificial so that they can meet the needs and activities of humans. The third is fragmentation which is a necessity of specialization in each individual worker so that it demands professionalism in work. And the last is individualism which is a human attitude characterized by the tenuous relationship of human interaction, and the increasing role of individuals in the daily activities of society.

Information Technology is growing rapidly from year to year which can unconsciously affect behaviors and habits, as well as patterns of interaction between people by millennials. The development of information technology has both positive and negative impacts for millennials. Millennials today tend to feel great in the use of technology because they were born in an era that has begun to change as the existence of color television, mobile phones, computers and others. They millennials prefer and are excited when interacting with outside cultures compared to their own culture, because it is considered left behind by ancient times and eras. Negative responses by millennials like this that endanger the sustainability of local culture and cause cultural degradation in Indonesia.

In fact, there is no denying that gadgets such as smartphones, Ipads and the like become tools that make their users 
dependent including millennials. If without the help of gadgets just a day the millennial generation feels unable to maximize their daily activities. But the main mistake that is often made by millennials is to not know the limits or rules or norms that exist as if forgetting the norms or limits that should be considered in doing activities using the help of information technology tools, this is what triggers moral damage that often occurs today in this nation. Millennials tend to have a mindset that required a style of dress, a way of connecting with others that is not like teenagers in an era where there is no sophistication of information technology. Millennials including those living in urban areas prefer to adopt a lifestyle of hedonism, where they attach importance to pleasure or interest - sprees with their peers without regard to rules in their financial management, millennials in urban areas with the characteristics of hedonism as those who are more concerned with the material of everything, the presence of those who want to be recognized by the surroundings so as to create unhealthy competition, It is the duty of millennials to be able to change their hedonism lifestyle into a simpler lifestyle that is not thirsty by temporary recognition.

The behavior of millennials today is clearly seen that most of them adhere to a free and unbound lifestyle which is very worrying. Because basically life with such a pattern is not a characteristic of our cultural lifestyle that is still guided by eastern cultural ancestors, the consequences of this behavior make millennials do things that according to cultural guidelines lelhur taboo is done, but because of the occurrence of cultural degradation so that the taboo is still done and considered ordinary by millennials, This habitual behavior cannot be left alone because sooner or later it will affect the community which can also result in mental damage. By seeing and knowing clearly that the potential for greater cultural generalization, certainly arises in our minds what about the regulation of hukun which becomes protective of the dangers that threaten local culture. Speaking of legal issues, of course, it is not far from talking about the apparatus and facilitators in it, how the roles they have done to protect the threat that has been increasingly difficult to overcome, with 
this is expected the need for action from government officials in enforcing strict regulations by limiting sites on the internet that can damage morals or trust for its users. or locations that contain negative elements in it, give decisive action to article sites that contain SARA, begin to realize the preparation of science and technology development strategies that are not based on value-free, but value based (based on values) because this is important and takes precedence by using moral values, ancestry, and personality of the nation, because of the free values that are the mastermind of cultural degradation. This is important in the future so that the community in today's technological era remains an individual who has a religious and moral attitude that does not rely on technology above everything else without having an attitude of divinity and faith in Him.

The legal concept that has been created in Indonesia to protect local cultural heritage in a container that is right to be used as a basic material for mutual reference. This is still not good because it is still lagging behind because of the range of information provided by high technological advances.
Laws or provisions regarding socioculture are seen only as sweeteners in UUITE. By knowing this, it is expected that the role of regulators to be able to realize legislative regulations that are firm and dynamic so as to prevent the worsening degradation of local culture.

The solution of the impact of technological progress can be done by first realizing that the development of technological progress arises as a result of modernity and one of the efforts in the existence of society. Thus we can follow up by realizing the negative impact of technological progress is our main task in the search for solutions. What is very necessary is a common existence in every society that in doing so makes us have the desire for the descendants of the next generation to be intelligent and dignified. The desired expectation will be carried out if supported by the surrounding role such as parents, educational institutions, and the government so that with their help can prevent negative impacts that affect many young people. The role of the family that can be done in this problem is that the family should instill moral understanding and faith in their children early on, by familiarizing a 
good example to them so that when they are teenagers they are not affected by poor association due to the recognition competition that is often done by teenagers due to the negative impact of technological advances.

Watching television with family and children is good, but it has become an obligation for parents in arranging what shows should not be watched when watching with minors, it is important that children of the elderly who are underage can avoid negative spectacle so that when they are teenagers they can become a smart teenager.

The society also has a role that includes as technology users or consumers, the public should first filter all the information they receive, not just received and trusted just like that. Another role owned by manufacturers who produce technology products, should be as a technology manufacturer not only think about marketing and profit problems, but also pay attention to products that will be marketed to consumers that are good and useful and do not add to the severity of the negative impact of technological advances.

\section{CONCLUSION}

The rapid advancement of technology is causing a negative impact on local cultural heritage through the behavior of millennials in urban areas that tend to be increasingly affected by technological advances. Millennials who are actually creative and innovative but in fact opposites who boast a western lifestyle reflected by the behavior of hedonism, individualist, free lifestyle that underestimates morals. The handling that can be done is to provide understanding to millennials about the morality of the nation on the basis of Pancasila so that they can be implemented in everyday life. The cultural degradation that is occurring due to this can be minimized by the strong sense of nationalism in society. The role of the government in this case is very necessary by affirming the regulations and sanctions in the event of internet abuse. Currently there are government regulations in uuite and the 1945 constitution, but in reality on the ground still can not be fully as protection because of the 
gradation of local cultural values that are increasingly real. Therefore, government regulations are needed in accordance with the rapid development of information technology advances that are dynamic so that cultural degradation can be prevented.

\section{REFERENCES}

Pusat Bahasa. 2011. Kamus Besar

Bahasa Indonesia. Jakarta. Balai

Pustaka. Sztompka, Piotr. 2011.

Sosiologi Perubahan Sosial. Jakarta.

Prenada Media Group.

Tumanggor, Rusmin. 2010. Ilmu

Sosial dan Budaya Dasar. Jakarta.

Kencana Prenada Media Group.

Martono, Nanang. 2012. Sosiologi Perubahan Sosial: Perspektif Klasik, Modern, Postmodern, dan Poskolonial. Jakarta. PT. Raja Grafindo Persada.

Jess Feist, Gregory J. Feist, 2011. Teori Kepribadian: Jakarta, Salemba Humanika.

Slavin Robert. 2011. Psikologi Pendidikan Teori dan Praktek. Jakarta: PT Indeks. Undang Dasar 1945.
Sebastian, Yoris, dkk., 2016. Generasi Langgas Millenials Indonesia. Jakarta: Gagas Media.

Sulasman dan Gumilar. 2013. TeoriTeori Kebudayaan Dari Teori Hingga Aplikasi. Bandung: CV. Pustaka Setia.

Ramly, Nadjamuddin. 2010. Pendidikan Pembangunan Karakter Bangsa, Strategi, Masalah dan Prospek Masa Depan Jakarta: Grafindo Khazanah Ilmu, Horton, Paul B. dan Chester L Hunt, 1987. Sosiologi, Jilid I. Terj. Aminudin Ram \& Tita Sobari. Jakarta: Erlangga, 1987. 208. 